площадью (до 100 м), малочисленная (около 20-90 особей), растет группами по 5-20 на м². Вид входит в состав формации Phragmitetum australis, Cariceta flava, Cariceta nigra, который образует ассоциации Phragmites australis + Carex flava + Carex nigra.

Ключевые слова: Pinguicula vulgaris, мониторинг, гетеротрофный, гелиофиты, формация, ассоциация, ценопопуляция, особь.

Skakal's'ka Olga, Batochenko Volodumur. Chorology and Growth Characteristics Pinguicula Vulgaris L. Within the Territory of Brody District (p. Batkov, Lviv Region.). The article reported the discovery Pinguicula vulgaris L. within wetlands with. Batkiv, Brody district, Lviv region. The results of the study of rare, listed in the Red Book of Ukraine heterotrophic heterotrophic species $P$. vulgaris. Posted geographical spread of this type, the results of geobotanical, phytocoenotic research, ecology habitat type. Deals with the data on the number of individuals in coenopopulations in the monitoring area. The population of P. vulgaris L. small area (100 m) of small, about 20-90 individuals, groups grows 5-20 $\mathrm{m}^{2}$. Type part of the formation Phragmitetum australis, Cariceta flava, Cariceta nigra, which forms association Phragmites australis + Carex flava + Carex nigra.

Key words: Pinguicula vulgaris, monitoring, heterotrophic, heliofit, formation, association, coenopopulations, individual.

Стаття надійшла до редколегії 16.02.2016 p.

УДК $581.93(477.8)$

\author{
Марія Стасюк, \\ Сергій Лико
}

\title{
Історія вивчення адвентивної фракції флори Волинської височини
}

У флорі України зараз немає жодного флорокомплексу, у якому б не брали участь адвентивні рослини. Інвазійні адвентивні рослини вкорінюються навіть у деревно-чагарникових ценозах, які мають найбільш стійку структуру.

Упродовж усієї історії дослідження рослинного світу Волинської височини спеціального вивчення видового складу, поширення адвентивних рослин, їхніх еколого-ценотичних умов зростання, структури популяцій не проводили. Проте в працях деяких науковців наведено фрагментарні відомості про видовий склад рослин окремих міст і їхніх околиць, які представлені в загальних флористичних зведеннях.

У статті досліджено перші відомості про флору Волинської височини, наведені на початку XIX ст. в роботах В. Г. Бессера, Фогеля, Й. Юндзіла, В. С. Доктуровського. Проте вчені не вказували конкретних місцезнаходжень більшості видів. Окремі види адвентивних рослин у межах території Волинської височини описано в працях ботаніків із другої половини XIX ст.: О. С. Роговича, В. В. Монтрезора, Й. К. Пачоського, І. Ф. Шмальгаузена, М. А. Троїцького, Й. Панека, С. Мацко, А. І. Барбарича. Однак у цих роботах адвентивні рослини в окрему групу не виділено.

Ключові слова: адвентивна фракція флори, Волинська височина, історія вивчення.

Постановка наукової проблеми та їі значення. У флорі України зараз немає жодного флорокомплексу, у якому б не брали участь адвентивні рослини [12]. Вивчення неаборигенної фракції флори України розпочалося з окремих видів заносних рослин разом із видами природної флори й на початкових етапах проводилося переважно окремими вченими та флористами університетів, які, подорожуючи в межах порівняно невеликих територій, досліджували місцеву флору.

Аналіз досліджень цієї проблеми. Волинська височина, або Волинське лесове плато, лежить у південно-західній, найбільш припіднятій частині Східноєвропейської рівнини. Вона є складовою частиною Волино-Подільської височини та являє собою іiі північну частину, виокремлену від Подільської височини вузькою смугою Малого Полісся. На півночі Волинське лесове плато межує 3 Поліською низовиною, на сході - із Житомирським Поліссям, на заході - із Люблінською височиною, від якої Волинське плато відмежоване долиною р. Західний Буг [7].

У зв'язку з особливостями природних і соціально-історичних умов процеси адвентизації флори на території Волинської височини, на відміну від південних регіонів України, ще декілька десятиріч

(C) Стасюк М., Лико С., 2016 
тому особливо не виявлялися й не привертали уваги ботаніків. Однак у регіоні поступово почали складатися передумови, що сприяли занесенню та натуралізації заносних рослин. Виникнення таких передумов пов'язане із загальним прогресом людства в матеріальній і науково-технічній сферах, із розвитком процесів глобалізації ринку й економіки, що стали охоплювати й територію регіону. Тут спостерігали розширення площ міст і зростання чисельності міського населення, зростання масштабів промислового та аграрного виробництв, збільшення асортименту культивованих квітково-декоративних видів і форм рослин, активізацію транспортних зв'язків, осушення та освоєння осушених земель.

Аналіз досліджень цієї проблеми. Використовуючи літературні матеріали, опрацювавши гербарні фонди Національного гербарію Інституту ботаніки ім. М. Г. Холодного НАН України (KW), Національного університету ім. Тараса Шевченка (KWU), Національного ботанічного саду ім. М. М. Гришка НАН України (KWHA), Державного природознавчого музею НАН України у Львові (LWS), Львівського національного університету ім. Івана Франка (LW), Східноєвропейського національного університету ім. Лесі Українки (LUU), Волинського (LUM) і Рівненського (PKM) краєзнавчих музеїв, кафедри агрохімії, грунтознавства та землеробства Національного університету водного господарства та природокористування (м. Рівне), ми встановили, що впродовж усієї історії дослідження рослинного світу Волинської височини спеціального вивчення адвентивної фракції флори не проводили, проте в працях деяких дослідників наведено фрагментарні відомості про видовий склад рослин окремих міст і їхніх околиць, які представлено в загальних флористичних зведеннях. Перші відомості про флору Волинської височини наведено на початку XIX ст. в роботах В. Г. Бессера [22], Э. Фогеля [19], Й. Юндзіла [23], В. С. Доктуровського [3]. Проте науковці для більшості видів не вказували конкретних місцезнаходжень. Окремі види адвентивних рослин у межах території Волинської височини описуються в працях ботаніків із другої половини XIX ст.: О. С. Роговича [15], В. В. Монтрезора [6], Й. К. Пачоського [9, 10], І. Ф. Шмальгаузена [20, 21], М. А. Троӥцького [16], Й. Панека [25, 26], С. Мацко [24], А. І. Барбарича [1]. Однак у цих розвідках адвентивні рослини в окрему групу не виділено.

У першій половині XIX ст. флору на території Волинської височини вивчав відомий природознавець В. Г. Бессер, який, зокрема, відвідав Рівненський, Острозький і Дубенський повіти [21]. Різноманітні флористичні відомості містяться в низці його робіт (Besser, 1820, 1823, 1827, 1832).

У другій половині XIX ст. ботанічні дослідження пов'язані з діяльністю Київського університету, відкритого в 1834 р. Саме при ньому в 1869 р. засновано Товариство дослідників природи, за участю членів якого й проводилися різноманітні дослідження. У цей період значну увагу приділено вивченню флори в межах колишнього Київського навчального округу, до якого входила й Волинська губернія, приділив О. С. Рогович (Рогович, 1862). Усі результати досліджень автора флори Київського навчального округу наведено в його узагальнюючій праці (1869). У період 1870-1890 рр. опубліковано списки рослин окремих районів Волині, переважно західної частини, а також здійснено опис нових для науки видових таксонів. О. С. Рогович [15] для досліджуваної території указує 34 види неаборигенних рослин, місцезнаходження яких підтверджено гербарними зборами з м. Устилуга (Spergula arvensis L., Ribes rubrum L., Lamium purpureum L.), м. Володимира-Волинського (Lycium barbarum L., Bupleurum rotundifolium L., Valerianella dentata (L.) Poll.), м. Луцька (Descurainia sophia (L.) Webb ex Prantl, Vicia hirsuta (L.) S. F. Gray, Fallopia convolvulus (L.) A. Loeve), м. Дубно (Datura stramonium L., Nicandra physaloides L.) та м. Рівного (Veronica triphyllos L., Verbena officinalis L., Atriplex sagittata Borkh.).

У флористичних роботах В. Монтрезора [6] у розділі «Волинь» наявні відомості про види флори Волинської височини, де він охарактеризував 19 видів флори регіону, серед яких ми виділили три адвентивні види: Euphorbia falcata L., Caucalis platycarpos L. для м. Володимира-Волинського та Papaver argemone L. для м. Устилуга.

Загалом усю цінну флористичну інформацію цього періоду узагальнено в монографії І. Ф. Шмальгаузена [20]. Так, у праці «Флора Средней и Южной России, Крыма и Северного Кавказа» автор подає конкретні географічні пункти, де відзначено певні види. Саме для Волинської височини наведено 884 місцезнаходження: 25 указаних пунктів - 3 околиць Рівного, 59 - 3 околиць м. ВолодимираВолинського, 16 - 3 околиць м. Луцька, 5 - $з$ околиць м. Устилуга, $4-3$ околиць м. Дубна, 3 3 околиць м. Горохова, 6 - $з$ околиць м. Острога, 2 - 3 околиць Рожища, 3 - з околиць Здолбунова. Ця монографія стала найвизначнішим явищем у флористичній літературі України кінця XIX ст. I. Ф. Шмальгаузен наводить 14 заносних видів рослин, які стосуються території Волинської висо- 
чини [21]. Для окремих із них він зазначає конкретні локалітети: м. Володимир-Волинський (Caucalis platycarpos L., Trigonella caerulea (L.) Ser., Orobanche ramosa L.), м. Рівне (Lepidium perfoliatum L., Thlaspi arvense L., Veronica triphyllos L.), м. Здолбунів (Valerianella rimosa Bast.), м. Устилуг (Conringia orientalis (L.) Andrr.).

Будучи учнем I. Ф. Шмальгаузена, В. I. Липський [18] теж брав учать у наукових експедиціях товариства дослідників природи. Декілька звітів про експедиції учений опублікував у «Записках Київського товариства дослідників природи». У м. Володимирі-Волинському В. І. Липським відзначено три адвентивні види - Verbena officinalis L., Nepeta cataria L. та Stachys annua. L.

Досліджуючи флору Полісся, Й. К. Пачоський обстежив північну частину території Волинської височини. Він детально дослідив околиці м. Володимира-Волинського, місцевість навколо с. Пирятин Дубнівського повіту. За матеріалами власних досліджень 1890 р. Й. Пачоський склав список рослин, який містив 455 видів, із них 432 відзначено в межах Повчанського пасма. Згодом учений долучив до списку ще 64 види рослин [10]. У своїй праці «Флора Полесья и прилежащих местностей» Й. К. Пачоський наводить 101 неаборигенний вид, при цьому для окремих із них зазначено, що вид $є$ заносним або здичавілою формою [11]. Наприклад: м. Устилуг (Descurainia sophia, Onobrychis viciifolia Scop., Rumex maritimus L.), м. Володимир-Волинський (Symphoricarpos albus (L.) S. F. Blake, Chenopodium polyspermum L., Euphorbia platyphyllos L.), м. Ківерці (Lepidotheca suaveolens (Pursh) Nutt.), м. Рівне (Camelina microcarpa Andrz., Agrostemma githago L., Sisymbrium loeselii L.), с. Пирятин Дубенський р-н (Valerianella rimosa, Myosotis arvensis (L.) Hill, Thymelaea passerina (L.) Coss. et Germ.), с. Тучин, Гощанський р-н (Apera spica-venti (L.) P. Beauv., Nepeta cataria L., Velarum officinale (L.) Reichb.), с. Гориньград, Рівненський р-н (Xanthoxalis dillenii (Jacq.) Holub, Malva neglecta Wallr., Euphorbia helioscopia L.), с. Великі Межирічі, Корецький р-н (Verbena officinalis L.), м. Корець (Erysimum cheiranthoides L., Xanthium spinosum L., Bromus secalinus L.).

Значним доповненням до досліджень Й. К. Пачоського є зведені списки флори м. Рівного та його околиць С. К. Фєдосєєва [17], із яких 60 видів є заносними: Symphyotrichum x salignum (Willd.) Nesom, Buglossoides arvensis (L.) Johnst., Tripleurospermum inodorum (L.) Sch. Bip. (м. Рівне), Leonurus cardiaca L., Sonchus arvensis L., Lathyrus tuberosus L. (мікрорайон Новий Двір, передмістя Рівного), Vicia villosa Roth, Anagallis arvensis L., Consolida regalis S. F. Gray (мікрорайон Тинне, передмістя Рівного), Oenothera biennis L. (с. Бармаки, Рівненський р-н).

У кінці XIX - на початку XX ст. у працях і звітах таких дослідників, як М. А. Троїцький [16] й А. I. Барбарич [1], наведено показники про знахідки деяких видів адвентивних рослин. Будучи учасником експедицій Товариства дослідників природи 1913-1914рр. 3 дослідження луків Волинської губернії, М. А. Троїцький відзначив зростання Impatiens parviflora DC., Lepidium perfoliatum L. у c. Городок, Рівненського р-ну та Geranium sibiricum L. у с. Тучин, Гощанського р-ну. Крім того, учений зробив критичний аналіз праць І. Ф. Шмальгаузена (1895-1897), В. Г. Бессера (1836), О. С. Роговича $(1861,1869)$, Й. К. Пачоського (1897), В. Монтрезора (1886). А. І. Барбарич, зі свого боку, здійснив огляд флористичних досліджень в Україні загалом та в західних областях, зокрема, i зафіксував Carduus nutans L. у с. Новомильськ Здолбунівського р-ну.

У 20-40-х роках XX ст. на території тодішньої Волині, яка входила до складу Польщі, вивченням флори, у тому числі й видами адвентивних рослин, займалися Panek J. i Macko S. [8], гербарні збори яких зберігаються у фондах Волинського й Рівненського обласних краєзнавчих музеїв [4]. Так, у фондах Рівненського обласного краєзнавчого музею зберігається 295 гербарних зразків Й. Панека. Крім того, у працях Й. Панека містяться детальні геоботанічні описи зі схемами та фотографіями рослинних угрупувань Вишневої гори [26]. Узагальнюючою стала відома праця Й. Панека «Roślinność stepowa i naskalna lessowego Wołynia», у якій автор велику увагу приділяє саме степовій рослинності.

Й. Панек наводить 70 неаборигенних видів для досліджуваної території: с. Караєвичі (Amaranthus retroflexus L., Salix fragilis L., Galinsoga parviflora Cav.), c. Рогачів (Anisantha tectorum (L.) Nevski, Trifolium hybridum L., Fagopyrum esculentum Moench), с. Грабів (Lathyrus tuberosus L., Digitaria ischaemum (Schreb.) Muehl., Oenothera biennis L.), с. Понебель (Lappula squarrosa (Retz.) Dumort., Stachys anпиa L.), с. Зозів (Setaria glauca (L.) P. Beauv., Nepeta cataria L.), с. Бронники (Phalacroloma annuит (L.) Dumort.), с. Городок (Impatiens parviflora DC., Cuscuta gronovii Willd. ex Schult., Fallopia convolvulus (L.) A. Loeve), с. Шубків (Portulaca oleracea L., Nepeta cataria L.), Рівненського р-ну, 
м. Рівне (Anchusa officinalis L., Sisymbrium loeselii L., Lamium amplexicaule L.), с. Новомильськ Здолбунівського р-ну (Diplotaxis muralis (L.) DC.), м. Здолбунів (Elaeagnus angustifolia L.), с. Брище Дубенського р-ну (Geranium sibiricum L.), м. Дубно (Valerianella rimosa Bast.), м. Луцьк (Veronica persica Poir.). По залізниці Рівне - Клевань автор зазначає Eragrostis minor Host.

Досить вагомий внесок у вивчення та охорону рослинного світу Волині й Волинської височини, зокрема, зробив С. Мацко [24]. Саме з ініціативи С. Мацко в Луцьку створено Волинський краєзнавчий музей, у якому й зберігається гербарний матеріал, зібраний ученим особисто (1924-1938рр.), а також частина гербарію не менш відомого природодослідника Й. Панека (1902-1937рp.).

У дослідженнях С. Мацко виділено 51 заносний вид: с. Холонів Горохівський р-н (Hyoscyamus niger L., Sonchus arvensis L.), м. Горохів (Setaria glauca (L.) P. Beauv., Malva neglecta Wallr., Euphorbia helioscopia L.), м. Луцьк та його околиці (Artemisia absinthium L., Erysimum cheiranthoides L., Senecio vulgaris L.), с. Грабів (Xanthium spinosum L.), с. Понебель (Carduus nutans L.), с. Караєвичі (Aethusa cynapium L., Matricaria recutita L., Buglossoides arvensis (L.) Johnst.), с. Городок (Elsholtzia ciliata (Thunb.) Hyl.) Рівненського р-ну, м. Рівне (Crepis rhoeadifolia M. Bieb., Thlaspi arvense L., Papaver rhoeas L.), м. Здолбунів (Nigella arvensis L.), с. Брище Дубенський р-н (Geranium sibiricum L.), Phalacroloma annuит (L.) Dumort. відзначено в с. Олика та с. Дерно Ківерцівського p-ну, с. Сокиричі Ківерцівського р-ну (Arabidopsis thaliana (L.) Heynh.), м. Ківерці (Lycopsis arvensis L., Lamium album L., Xanthoxalis dillenii (Jacq.) Holub).

Для м. Ківерці Oenothera biennis наводиться А. Мохлинською [18].

На початку 70-х років XX ст. значні узагальнення щодо видів адвентивних рослин для Лісостепу й Степу України зроблено В. В. Протопоповою. Інформація про поширення деяких видів адвентивних рослин, у тому числі й на території Волинської височини, приведено в працях автора [11, 13], на жаль, відсутні безпосередні вказівки на місцезростання видів.

В останні роки підсумовано дані про склад флори Волинської височини I. I. Кузьмішиною [5] (1404 види). Зокрема, науковець указує на збільшення частки іiї синантропної фракції та зростання ролі адвентивних видів, які нараховують 239 видів (Heracleum sosnowskyi Manden., Asclepias syriaca L., Hyoscyamus niger L., Ambrosia artemisiifolia L., Centaurea diffusa Lam., Solidago canadensis L., Digitaria aegyptiaca (Retz.) Willd., Hordeum leporinum Link та ін.). Проте це не дає змоги об’єктивно оцінити сучасний стан адвентивної фракції флори досліджуваної території.

Висновки та перспективи подальшого дослідження. Підсумовуючи історичний огляд вивчення флори Волинської височини, потрібно відзначити, що багато вчених займалося дослідженням флори окремих ділянок Волинського лесового плато, проте повне узагальнення про поширення адвентивних видів, їхні еколого-ценотичні умови зростання, структуру популяцій, інвазійну здатність адвентивних видів, ценозоутворювальні властивості та відносини з аборигенними видами наведено фрагментарно й представлено в загальних флористичних зведеннях.

\section{Джерела та література}

1. Барбарич А. І. До історії ботанічних досліджень на Українському Поліссі / А. І. Барбарич // Укр. ботан. журн. - 1961. - 18, № 5. - С. 99-106.

2. Бурда Р. І. Загроза біологічного забруднення довкілля України північноамериканськими видами / Р. І. Бурда, В. К. Тохтар // Укр. ботан. журн. - 1998. - 55, № 2. - С. 127-132.

3. Доктуровский В. С. Предварительный отчет об исследованиях болот Волынской губернии в 1913 г. / В. С. Доктуровский // Труды общества исследователей Волыни. - 7. - Житомир, 1913-1914. - С. 161-179.

4. Кузьмішина I. I. Гербарій Стефана Мацко у Волинському краєзнавчому музеї / I. I. Кузьмішина // Вісник Луганського держ. пед. ун-ту ім. Тараса Шевченка. - Серія : Біологічні науки. - Луганськ : Вид-во Луганського держ. пед. ун-ту ім. Тараса Шевченка, 2003. - № 11 (67). - С. $35-39$.

5. Кузьмішина I. I. Флора Волинської височини, іiі антропічна трансформація та охорона : дис... канд. біол. наук : 03.00.05 / I. І. Кузьмішина. - К., 2008. -278 с.

6. Монтрезор В. В. Обозрение растений, входящих в состав флоры губерний Киевского учебного округа: Киевской, Подольской, Волынской, Черниговской и Полтавской / В. В. Монтрезор // Записки Киевского общества естествоиспытателей. - Киев : Тип. И. Н. Кушнерева и К이 1887-1891. - Вып. 1-5.

7. Національний атлас України / Нац. академія наук України ; [ред. кол. : Б. Є. Патон та ін.]. - К. : Картографія, 2007. - 440 с.

8. Олешко В. В. Каталог гербарію Стефана Мацка та Йозефа Панека / В. В. Олешко, Л. А. Савчук, Т. П. Андрєєва. - Луцьк, 2005. - 582 с. 
9. Пачоский И. К. Флора Полесья и прилежащих местностей / И. К. Пачоский // Труды С.- Петербур. о-ва естествоиспытателей. - 1897. - Т. 27. - Вып. 2. - 103 с.; 1899 - Т. 29. - Вып. 3. - 113 с.; 1900. - Т. 30. Вып. 3. - 259 с.

10. Пачоский Й. О фауне и флоре окрестностей г. Владимира-Волынского / Й. Пачоский. - Киев, 1888. C. $1-82$.

11. Протопопова В. В. Адвентивні рослини Лісостепу і Степу України / В. В. Протопопова. - К. : Наук. думка, 1973. - 192 с.

12. Протопопова В. В. Вплив адвентивних видів рослин на фітобіоту України / В. В. Протопопова, С. Л. Мосякін, М. В. Шевера // Оцінка і напрямки зменшення загроз біорізноманіттю України / [відп. ред. О. В. Дудкін]. - К. : «Хімджест», 2003. - С. 129-155.

13. Протопопова В. В. Синантропная флора Украины и пути ее развития / В. В. Протопопова. - Киев : Наук. думка, 1991. - 204 с.

14. Протопопова В. В. Фітоінвазії в Україні як загроза біорізноманіттю: сучасний стан і завдання на майбутнє / В. В. Протопопова, С. Л. Мосякін, М. В. Шевера. - К. : Ін-т ботаніки ім. М. Г. Холодного НАН України, 2002. - 32 с.

15. Рогович А. С. Обозрение семенных и высших споровых растений, входящих в состав флоры губерний Киевского учебного округа: Волынской, Подольской, Киевской, Черниговской и Полтавской / А. С. Рогович. - Киев : Университет. тип., 1869. - 309 с.

16. Троицкий Н. А. О распространении некоторых растений в Волынской губернии / Н. А. Троицкий // Записки Киевского о-ва естествоиспытателей, 1917.- 25. - В. 2. - С. 69-70.

17. Федосеев С. К флоре Полесья. Несколько сведений о флоре окресностей г. Ровно, Волинской губернии / С. Федосеев // Труды С.-Петерб. о-ва естествоиспытателей. - 1897. - Т. 27. - Вып. 2. - С 261-281.

18. Флора УРСР. - К. : Наук. думка, 1950-1965. - Т. 3-12.

19. Фогель Э. Сведения о лесах в Волынской губернии / Э. Фогель // Лесн. журн. - 1836. - Ч. 1, кн. 2. C. 217-229.

20. Шмальгаузен И. Ф. Флора Средней и Южной России, Крыма и Среднего Кавказа / И. Ф. Шмальгаузен. Киев, 1895. - Т. 1. 468 с.; 1897. - Т. 2. - 752 с.

21. Шмальгаузен И. Ф. Флора Юго-Западной России, т. е. губерний: Киевской, Волынской, Подольской, Полтавской, Черниговской и смежных местностей. Руководство для определения семенных и высших споровых растений / И. Ф. Шмальгаузен. - Киев, 1886. - 783 с.

22. Besser W. Ennumeratio plantarum hucusque in Volhynia, Podolia gub. Kioviensi, Bessarabia cis Thyraica et circa Odessam collectarum simul cum observationibus in Primititas Flora Galiciae Austriacae / W. Besser. Vilnae, 1822. - $111 \mathrm{~s}$.

23. Jundziłł J. Opisanie rošlin w Litwie, na Wołyniu, Podolui Ukrainie dzikorosna cychjako ioswolonych / J. Jundziłł. - Wilno, 1830. - 583 s.

24. MackoS. Roślinność okolic Łucka / S. Macko // Ziemia. Rocznik XXVII. -1937. - № 11-12. - S. $235-240$.

25. Panek J. Roślinność okolic Rownego / J. Panek // Rocznik Wolynski. - Rowno, 1930. - Cz. 1. - S. 31-56.

26. Panek J. Wiśniowa GóranaWołyniu / J. Panek // Ochrona przyrody. Rocznik 13. - Kraków, 1933. - S. 72-78.

Стасюк Мария, Лыко Сергей. История изучения адвентивной фракции флоры Волынской возвишености. Во флоре Украины сейчас нет ни одного флорокомплекса, в котором бы не участвовали адвентивные растения. Инвазионные адвентивные растения укореняются даже в древесно-кустарниковых ценозах, которые имеют наиболее устойчивую структуру.

На протяжении всей истории исследования растительного мира Волынской возвышенности специального изучения видового состава, распространения адвентивных растений, их эколого-ценотических условий роста, структуры популяций не проводилось. Однако в трудах некоторых исследователей есть фрагментарные сведения о видовом составе растений отдельных городов и их окрестностей, которые представлены в общих флористических сводках.

В статье исследуются первые сведения о флоре Волынской возвышенности, которые приведенные в начале XIX в. в работах В. Г. Бессера, Фогеля, И. Юндзила, В. С. Доктуровського. Однако ученые для большинства видов не указывали конкретных местонахождений. Отдельные виды адвентивных растений в пределах территории Волынской возвышенности описываются в трудах ботаников со второй половины XIX в. (А. С. Роговича, В. В. Монтрезора, И. К. Пачоского, И. Ф. Шмальгаузена, М. А. Троицкого, И. Панек, С. Мацко, А. И. Барбарич). Только в этих работах адвентивные растения в отдельную группу не выделены.

Ключевые слова: адвентивная фракция флоры, Волынская возвышенность, история изучения.

Stasiuk Mariay, Lyko Sergii. The History of Study of the Alien Flora Fraction of Volyn Upland. All of Ukrainian floral complexes nowadays have alien plants in their structure. Invasive alien plants root even in trees and shrubs cenosis which have the most stable structure. 
Special study of the species, the spread of alien plants, their ecological-coenotic conditions of growth and structures of population were not implemented throughout all history of flora investigation in Volyn Upland. However, works of some researchers contain fragmentary information on species composition of individual cities and their suburbs, which are presented in general floristic summaries.

This article researches the first information about flora of Volyn Upland which was mentioned in the works of B. H. Besser, Vogel, J. Yundzila and B. S. Dokturovskiy in the beginning of the $19^{\text {th }}$ century. However, the authors did not point out to specific location of most species. Some species of alien plants within the territory of Volyn Upland were described in works of botanists from the second half of the $19^{\text {th }}$ century: O. S. Rogovich, V. V. Montrezor, J. K. Pachoskiy, I. F. Shmalgauzen, M. A. Troitskiy, J. Panek, S. Matsko, A. I. Barbarych. However, the alien plants were not selected into the separate group in those works.

Key words: adventive fraction of flora, Volyn Upland, history of flora investigation.

Стаття надійшла до редколегії 30.02.2016 p.

УДК 581.524.1

\section{Марина Шерстюк}

\section{Морфометричні ознаки Oxycoccus palustris Pers. у болотних та лісоболотних фітоценозах Українського Полісся}

Охарактеризовано величини 14 статичних метричних та шести статичних алометричних морфопараметрів рослин Oxycoccus palustris Pers. у чотирьох фітоценозах Українського Полісся. Показано, що особини з різних рослинних угруповань статистично достовірно відрізняються між собою величинами майже всіх розмірних показників. Установлено, що значення більшості статичних метричних морфопараметрів у рослин $O x y c o c c u s$ palustris зростають у такій послідовності екоряду фітоценозів: Betuleto (pubescentis)-Pinetum (sylvestris) vaccinioso (myrtilli)-sphagnosum (cuspidati) $\rightarrow$ Betuleto (pubescentis)_Pinetum (sylvestris) eriophoroso (vaginati) sphagnosum (cuspidati) $\rightarrow$ Pinetum (sylvestris) sphagnosum (cuspidati) $\rightarrow$ Sphagnetum (cuspidati) eriophorosum (vaginati). Доведено, що в кожному фітоценозі формуються особини зі специфічною морфоструктурою. Для досліджуваних угруповань визначено характерні морфоознаки рослин Oxycoccus palustris та побудовано їхні морофограми.

Ключові слова: Oxycoccus palustris Pers., автохтонні дендросозофіти, ценопопуляції, морфометричний аналіз, модельні особини, Українське Полісся.

Постановка наукової проблеми та їі значення. У сучасному світі проблема забезпечення збереження фіторізноманіття планети не втрачає своєї актуальності, про що наочно свідчить зміст оновленої версії Глобальної стратегії збереження рослин на 2011-2020 pp. [4]. Зі свого боку, існування рослин у тих чи інших екоумовах визначається за ступенем їхньої пристосованості до них, у тому числі завдяки реалізації здатності до морфоадаптацій $[3,8,9,16]$. Прояв у зовнішній будові особин певних ознак, які сприяють виживанню та успішній життєдіяльності у відповідних місцезростаннях, особливо важливо для раритетних видів фіторізноманіття. В Українському Поліссі до таких рослин, зокрема, належать автохтонні дендросозофіти: види місцевої флори, які мають офіційний статус на різних рангах охорони (міжнародному, загальнодержавному або регіональному) [6]. Їхнім представником є Oxycoccus palustris Pers., яка включена до Списку рослин, що підлягають особливій охороні на території Хмельницької, Сумської й Чернігівської областей [1].

На сьогодні в науковій літературі накопичений значний обсяг інформації про поширення O. palustris [5] та iї ресурсний потенціал в окремих регіонах [14], хімічний склад органів [13, 15], лікарські властивості $[2,18]$, можливість і перспективність штучного вирощування $[11,12]$, а також про певні аспекти господарського використання $[17,18]$. Однак питання щодо прояву в цього виду морфоадаптацій і змін габітусу особин залежно від умов місцезростань залишається майже не дослідженим.

(С) Шерстюк М., 2016 